\title{
Sistem Pergerakan dan Deteksi Pada Robot Sepak Bola Beroda Berbasis Image Processing dengan Penerapan Multivision
}

\author{
Risfendra $^{1}$, Aldo Aulia Akbar ${ }^{1 *}$ dan Firdaus ${ }^{2}$ \\ ${ }^{1}$ Jurusan Teknik Elektro, Fakultas Teknik, Universitas Negeri Padang \\ ${ }^{2}$ Jurusan Teknik Elektro, Departemen Teknik Elektro, Politeknik Negeri Padang \\ *Corresponding author, e-mail: aldouliakbr81@gmail.com
}

\begin{abstract}
Abstrak-Penelitian ini bertujuan untuk membangun robot sepak bola beroda yang bergerak holonomic berbasis image processing untuk melakukan pendeteksian bola yang selanjutnya data tersebut menjadi kondisi pergerakan robot pada pertandingan. Sistem pergerakan robot pada penelitian ini menggunakan konfigurasi 3 roda omni yang membuat robot dapat bergerak secara holonomic. Image processing pada penelitian ini digunakan sebagai sistem deteksi bola pada robot yang diproses menggunakan laptop dan dibuat dengan bahasa pemograman python menggunakan pustaka open computer vision. Permasalahan yang sering terjadi pada sistem pendeteksian objek menggunakan satu kamera adalah keterbatasan area pendeteksian objek pada robot. Sehingga pada penelitian ini digunakan metode color filtering $\mathrm{HSV}$ dengan penerapan pada multivision. Penerapan metode pada penelitian ini bertujuan untuk meningkatkan jarak pendeteksian objek yang dipengaruhi oleh reliabilitas segmentasi warna serta memperluas area pendeteksian objek pada robot. Kamera 1 digunakan untuk mendeteksi objek yang berada $120^{\circ}$ di depan robot dan kamera 2 digunakan untuk mendeteksi objek yang berada $360^{\circ}$ disekitar robot. Sehingga diperoleh kondisi - kondisi yang dapat memperbaiki kinerja pada sistem pergerakan robot. Hasil dari image processing menjadi data input sensor yang diterima oleh arduino mega 2560, pengiriman data tersebut menggunakan komunikasi serial port USB. Hasil penelitian menunjukkan bahwa kamera 1 dapat melakukan pendeteksian bola dengan jarak 0 - $12 \mathrm{~m}$, dan kamera 2 dapat melakukan pendeteksian bola dalam radius 0 - 4 meter.
\end{abstract}

Kata Kunci : Image Processing, Color Filtering HSV, Multivision

\begin{abstract}
This study aims to build a wheeled soccer robot that moves holonomically based on image processing to detect the ball, which then becomes the condition of the robot's movement in the match. The robot movement system in this study uses 3-wheel configuration that allows the robot to move holistically. Image processing in this study is used as a ball detection system in robots that is processed using a laptop and made in the python programming language using open computer vision libraries. The problem that often occurs in object detection systems using one camera is the limited area of object detection on the robot. This study used the HSV color filtering method with the application of multivision. The application of the method in this study aims to increase the object detection distance which is influenced by the reliability of color segmentation and to expand the object detection area of the robot. Camera 1 is used to detect objects that are $120^{\circ}$ in front of the robot and camera 2 is used to detect objects that are $360^{\circ}$ around the robot. In order to obtain conditions that can improve the performance of the robot movement system. The results of image processing become sensor input data received by Arduino Mega 2560, sending data using the USB port serial communication. The results shows that camera 1 can detect a ball with distance of 0 - $12 \mathrm{~m}$, and camera 2 can detect a ball within radius of 0 - 4 meters.
\end{abstract}

Keywords : Image Processing, Color Filtering HSV, Multivision

This is an open access article distributed under the Creative Commons 4.0 Attribution License 


\section{Pendahuluan}

RoboCup Middle Size League (MSL) atau sepak bola robot dunia adalah ajang sepak bola robot beroda yang mana robot sepak bola beroda dirancang mampu dalam bermain sepak bola seperti pertandingan sepak bola pada umumnya.

Robot sepak bola beroda dikembangkan menggunakan image processing, proses dalam memperbaiki nilai dari suatu citra dengan komputer, untuk menjadikan suatu citra yang mempunyai nilai yang semakin baik dari sebelumnya sehingga lebih mudah diinterpretasikan oleh manusia maupun mesin disebut sebagai image processing.

Pada robot sepak bola beroda, metode deteksi objek yang berbasis image processing dibutuhkan dalam mendeteksi objek yang berada pada lapangan pertandingan yaitu berupa bola. Permasalahan yang sering terjadi pada sistem pendeteksian objek adalah keterbatasan area pendeteksian objek pada robot. Oleh karena itu, pada penelitian ini penerapan image processing menggunakan dua kamera webcam sebagai sensor sehingga disebut multivision, yang bertujuan untuk memperluas area pendeteksian objek pada robot. Sehingga robot mampu mendeteksi objek yang berada $120^{\circ}$ di depan robot dan yang berada $360^{\circ}$ disekitar robot secara bersamaan. Dengan memanfaatkan kamera sebagai sensor, robot mendapatkan data informasi keberadaan objek dilapangan[1].

Ada beberapa contoh model ruang warna yang digunakan pada image processing diantaranya adalah RGB (Red, Green, Blue), CMYK (Cyan, Magenta, Yellow, Black), HSL (Hue, Saturation, Lightness) dan HSV (Hue, Saturation, Value). [2] Model ruang warna yang masih digunakan hingga sekarang dapat dilihat pada gambar 1 .

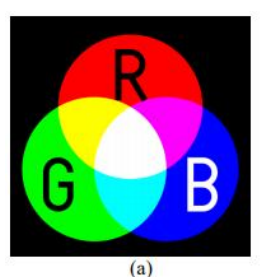

(a)

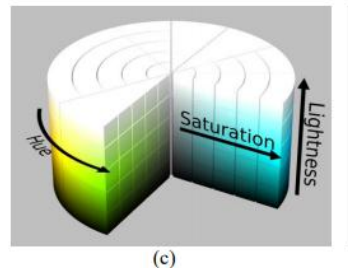

(c)

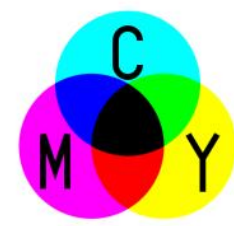

(b)

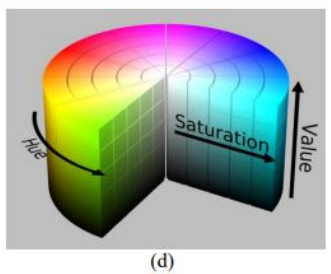

Gambar 1. (a) Ruang Warna RGB, (b) Ruang Warna CYMK, (c) Ruang Warna HSL, (d) Ruang Warna HSV.
Pada gambar 1 dapat dilihat bahwa model ruang warna RGB dan CYMK dibentuk dari komposisi warna pokok [3]. Ruang warna RGB dan CYMK belum memperhitungkan lightness dan value. Sementara model ruang warna HSV dan HSL telah memperhitungkan hal tersebut. Pada penelitian ini objek yang akan dideteksi adalah bola berwarna jingga sehingga parameter yang akan diambil adalah nilai ambang warna pada objek, model ruang warna HSV memiliki keuntungan dalam pemisahan nilai luminasi atau nilai kecerahan yang membuat pemilihan range warna mempunyai jarak yang cukup untuk dibedakan [2].

Pada penelitian ini metode color filtering HSV berfungsi untuk meningkatkan jarak pendeteksian objek yang dipengaruhi oleh reliabilitas segmentasi warna [1]. Metode ini juga dapat mengatasi kelemahan pada model ruang warna lain. Model ruang warna HSV (Hue, Saturation, Value) adalah contoh dari ruang warna yang mampu dilihat oleh mata manusia yang berfokus kepada ruang warna tersier [4].

Pada penelitian ini metode color filtering HSV diterapkan pada multivision. Dengan tujuan penerapan sistem deteksi objek menggunakan dua buah kamera dengan metode yang sama secara bersamaan tetapi dengan perbadaan sudut area deteksi sehingga menghasilkan algoritma yang dapat meningkatkan efektifitas pergerakan robot. Penggunaan 1 buah kamera memiliki berbagai kekurangan salah satunya disaat objek berada disisi kanan atau sisi kiri robot diluar area deteksi kamera yang hanya bisa menangkap $120^{\circ}$ maka robot hanya memiliki pilihan untuk berputar ke satu arah sehingga memiliki kemungkinan ketidakefektifan pergerakan.

Sementara penggunaan 2 kamera pada robot dapat menghasilkan pergerakan yang lebih efektif karena jika kamera 1 yang berfungsi melihat objek yang berada $120^{\circ}$ di depan robot kehilangan objek yang dideteksi maka kamera 2 akan memberikan informasi objek yang berada $360^{\circ}$ disekitar robot sehingga robot memiliki lebih banyak pilihan kondisi untuk berputar kearah objek tersebut.

Robot yang hanya menggunakan 1 buah kamera $360^{\circ}$ sebagai sistem deteksi juga memiliki kelemahan yaitu proses pendeteksian objek pada robot terbatas oleh jarak deteksi. Hal ini disebabkan karena kamera $360^{\circ}$ adalah kamera yang memanfaatkan pantulan dari cermin cembung sehingga hasil citra yang diperoleh kurang tajam. Maka dari itu pada penelitian ini menggabungkan 2 buah kamera atau multivision 
untuk memperluas area deteksi dan memperbesar jarak deteksi.

Hue adalah kategori warna dasar, yang merupakan letak warna tersebut dalam spektrum warna seperti merah, kuning dan biru. Saturasi (Saturation) suatu warna adalah parameter tingginya nilai warna yang disebabkan oleh pengaruh warna putih, seperti warna biru yang memiliki variasi dari warna biru tua hingga warna biru muda, dimana Hue tetap berwarna biru tapi nilai parameter saturasinya berbeda. Selanjutnya adalah value (intensitas) yang menjadi parameter kecerahan suatu warna, terdapat rentang nilai dari 0 - $100 \%$ pada value [5]. Model warna HSV dapat dilihat pada gambar 2 .

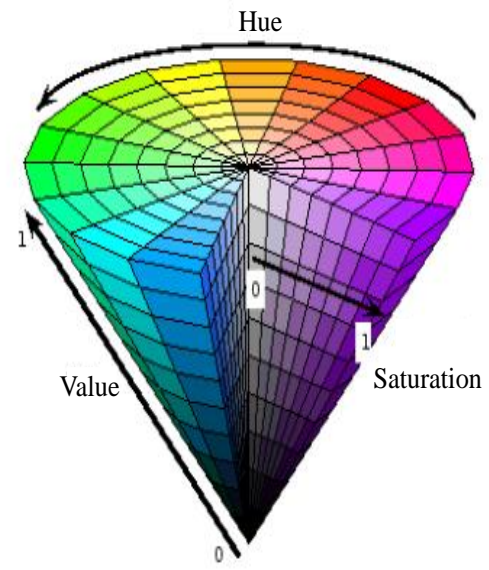

Gambar 2. Model Warna HSV

Model Warna HSV pada gambar 2 adalah model warna yang dapat dilihat oleh mata manusia [6]. Adapaun proses mengubah nilai RGB ke nilai HSV bisa penggunaan teori travis yang ada pada persaamaan (1)-(4).

$$
\begin{aligned}
& \boldsymbol{r}=\frac{\boldsymbol{R}}{\boldsymbol{R}+\boldsymbol{G}+\boldsymbol{B}}, \boldsymbol{g}=\frac{\boldsymbol{G}}{\boldsymbol{R}+\boldsymbol{G}+\boldsymbol{B}}, \boldsymbol{b}=\frac{\boldsymbol{B}}{\boldsymbol{R}+\boldsymbol{G}+\boldsymbol{B}} \\
& \mathrm{V}=\max (\mathrm{r}, \mathrm{g}, \mathrm{b}) \ldots \ldots \ldots \ldots \ldots \ldots \ldots \ldots \ldots \ldots \ldots \ldots \ldots \ldots \ldots \\
& 0, V=0 \\
& S=\left\{\begin{array}{c}
0, V=0 \\
1-\frac{\min (r, g, b)}{v}, V>0 \ldots \ldots \ldots \ldots \ldots \\
\frac{60 \times(g-V)}{S-V}, V=r \\
60 \times\left[2+\frac{b-r}{S \times V}\right], V=g \\
60 \times\left[4+\frac{r-g}{S \times V}\right], V=b
\end{array}\right.
\end{aligned}
$$

Setelah dilakukan pengolahan citra untuk mengkonversi citra ke HSV maka dilakukan proses color filtering dan thresholding. Color filtering adalah suatu cara untuk mengetahui piksel aktual dengan membatasi nilai tepi atas dan nilai tepi bawah untuk nilai piksel di gambar, jika gambar mempunyai nilai intensitas warna yang berada pada nilai tepi atas dan nilai tepi bawah yang ditentukan maka piksel tersebut dapat ke proses selanjutnya. Proses selanjutnya adalah thresholding, dimana piksel dari objek dan background diklasifikasikan dalam dua bentuk dominan.

Adapun cara untuk memisahkan objek dari background adalah menggunakan nilai threshold (T). Nilai $\mathrm{T}$ didapatkan melalui proses color filtering dengan penggunaan ruang warna HSV. Titik (x,y) yang mencukupi adalah titik objek, selain dari itu adalah titik background. Hasil dari thresholding dapat diperoleh dengan persamaan 5 .

$g(y, x)=\left\{\begin{array}{l}1, f(y, x)>T \\ 0, f(y, x) \leq T\end{array}\right.$

Keterangan :

$\mathrm{g}(\mathrm{y}, \mathrm{x})$ : Piksel Output

$\mathrm{f}(\mathrm{y}, \mathrm{x})$ : Piksel Input

$\mathrm{T}$ : Variabel ambang untuk threshold

Penentuan range warna yang sesuai sangat menentukan proses color filtering [5]. Untuk menyempurnakan hasil output dari proses color filtering dan thresholding maka diterapkan proses morfologi filter. Morfologi filter membutuhkan 2 input berupa gambar asli dan matriks structure element [7], morfologi filter memiliki 2 operasi standar yaitu erosi dan dilasi [8]. Erosi dan dilasi bertujuan menghapus noise pada citra gambar yang ada pada hasil pemfilteran HSV. Jika tidak ada noise pada gambar hasil filter HSV maka erosi dan dilasi tidak diproses [9]. Erosi dan dilasi diproses hingga noise yang ada pada gambar tidak ada sehingga objek dapat dideteksi akurat pada proses selanjutnya.

Setelah objek dapat dideteksi secara akurat maka diterapkan countours detection, yaitu mendeteksi objek berdasarkan bentuk objek dari hasil erosi dan dilasi. Sehingga objek yang diproses bisa diidentifikasi melalui bentuk countours objek tersebut. Apabila objek telah dideteksi maka akan diperoleh data koordinat berupa data (Xpixel,Ypixel) yang kemudian data koordinat tersebut dikirimkan ke kontroler. Data tersebut akan diolah oleh kontroler dan menjadi kondisi dari pergerakan robot.

Pada penelitian sebelumnya dilakukan perancangan robot beroda untuk mengikuti objek, kekurangan pada penelitian tersebut yaitu sistem pergerakannya tidak menggunakan roda omni sehingga robot tidak bergerak dengan dinamis [10].

Sistem differential drive pada robot sepak bola beroda dapat mewujudkan pergerakan yang 
dinamis kesegala arah atau disebut dengan pergerakan holonomic [11]. Sehingga pada penelitian ini dalam pergerakan robot digunakan konfigurasi dari kombinasi 3 roda omni yang memungkinkan robot untuk bergerak holonomic atau kesegala arah tanpa harus mengubah posisi hadap dari robot tersebut [12]. Konfigurasi dari 3 omniwheels merupakan sistem pergerakan robot yang efisien [13]. Konfigurasi ini membuat setiap roda omni terpisah sejauh $120^{\circ}$ dan memiliki sudut $30^{\circ}$ terhadap sumbu tegak [14]. Konfigurasi kinematika 3 omni-directional dapat dilihat pada gambar 3.

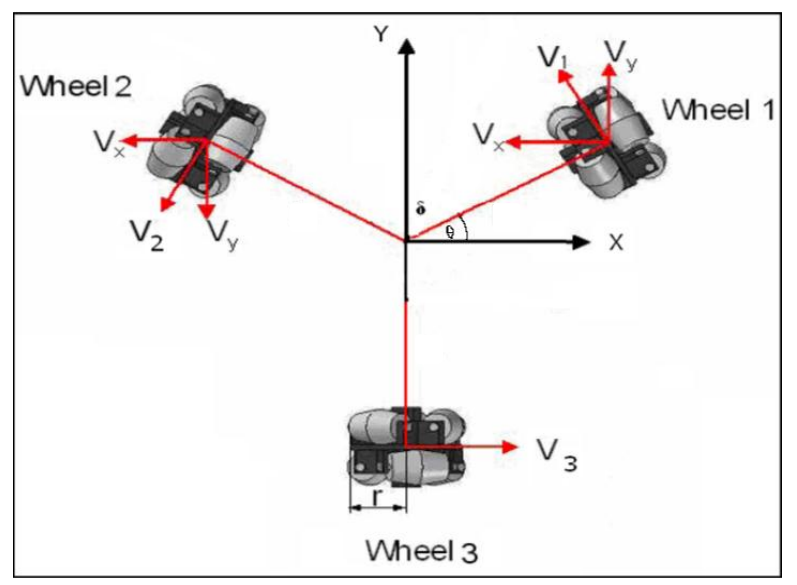

Gambar 3. Kinematika 3 Omni-Directional

Dari Gambar 3 didapatkan persamaan kinematika yang bisa digunakan pada robot sebagai berikut.

$\mathrm{V}_{\mathrm{y}}=\mathrm{V}_{1} \operatorname{Cos}(\theta)-\mathrm{V}_{2} \operatorname{Cos}(\theta)$

$\mathrm{V}_{\mathrm{x}}=\mathrm{V}_{3}-\mathrm{V}_{2} \operatorname{Sin}(\theta)-\mathrm{V}_{1} \operatorname{Sin}(\theta)$

Keterangan :

$\mathrm{V}_{1 / 2 / 3}=$ Kecepatan Linear roda $(\mathrm{m} / \mathrm{s})$

$\mathrm{V}_{\mathrm{x}} \quad=$ Kecepatan Linear pada sumbu $\mathrm{x}(\mathrm{m} / \mathrm{s})$

$\mathrm{V}_{\mathrm{y}} \quad=$ Kecepatan Linear pada sumbu y $(\mathrm{m} / \mathrm{s})$

$\theta \quad=$ sudut $\operatorname{roda}\left({ }^{\circ}\right)$

Pada penelitian ini penerapan kombinasi dari image processing menggunakan metode color filtering HSV pada multivision sebagai sistem pendeteksian objek dengan penggunaan konfigurasi 3 roda omni sebagai sistem penggerak holonomic pada robot sepak bola beroda dapat memperbaiki kinerja pada robot dan menghasilkan pergerakan yang lebih dinamis. Hal tersebut dikarenakan algoritma yang diterapkan lebih efektif. Sehingga memungkinkan robot untuk memiliki lebih banyak kondisi dalam melakukan pergerakan dibandingkan sistem pendeteksian objek menggunakan satu kamera, serta meningkatkan jarak pendeteksian objek.

\section{METODE}

\section{A. Blok Diagram}

Pada perancangan robot, input dari robot adalah objek yang dideteksi oleh kamera 1 dan kamera 2 pada pembacaan video secara realtime, apabila objek terdeteksi oleh salah satu kamera yang digunakan maka laptop akan mengolah objek tersebut menggunakan algoritma image processing. Hasil output dari pengolahan citra yang dilakukan oleh laptop akan dikirimkan kepada arduino dengan komunikasi serial. Data yang dikirimkan pada arduino tersebut diproses menjadi kondisi dari aktuator robot dalam melakukan pergerakan. Blok diagram $I / O$ dapat dilihat pada gambar 4.

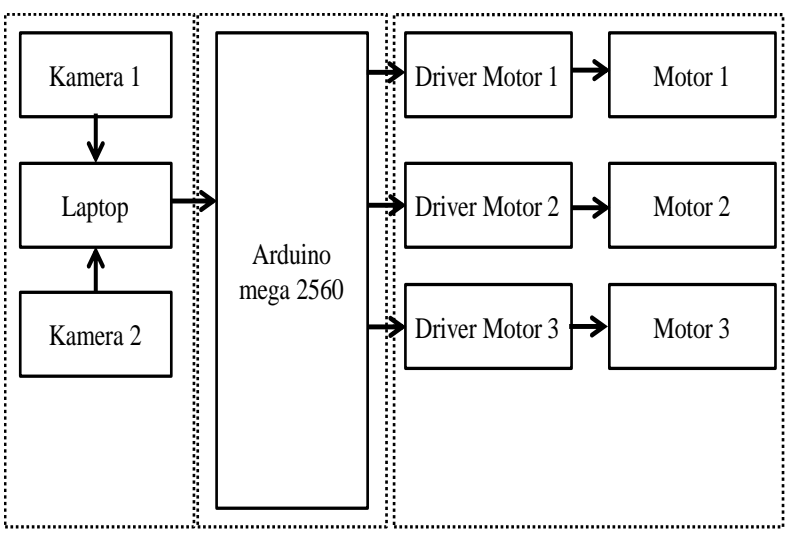

Gambar 4. Blok Diagram Alat

\section{B. Cara Kerja Alat}

Metode color filtering HSV yang digunakan pada penelitian ini yaitu, langkah pertama yang diproses oleh sistem adalah menjalankan proses pengambilan gambar dengan kamera 1, kamera 2, dan pengaturan pembatasan ukuran gambar yang diambil. Proses pengambilan gambar pada kedua kamera dilakukan secara realtime.

Lalu langkah kedua adalah gambar yang ditangkap oleh kamera diubah menjadi model warna HSV hal ini dapat dilakukan dengan mengaplikasikan persamaan 1-4. Langkah ketiga citra HSV akan dibinarisasi sehingga membuat citra menjadi dua bagian yaitu bagian objek dan background. Langkah keempat dilakukan proses thresholding untuk menentukan nilai ambang bawah dan nilai ambang batas yang bertujuan untuk memisahkan background dengan objek. Langkah kelima dilakukan proses filter morfologi untuk menghilangkan noise pada hasil pengolahan citra.

Selanjutnya adalah countours detection sehingga objek yang diproses bisa diidentifikasi melalui bentuk countours objek tersebut. 
Flowchart color filtering HSV dapat dilihat pada gambar 5.

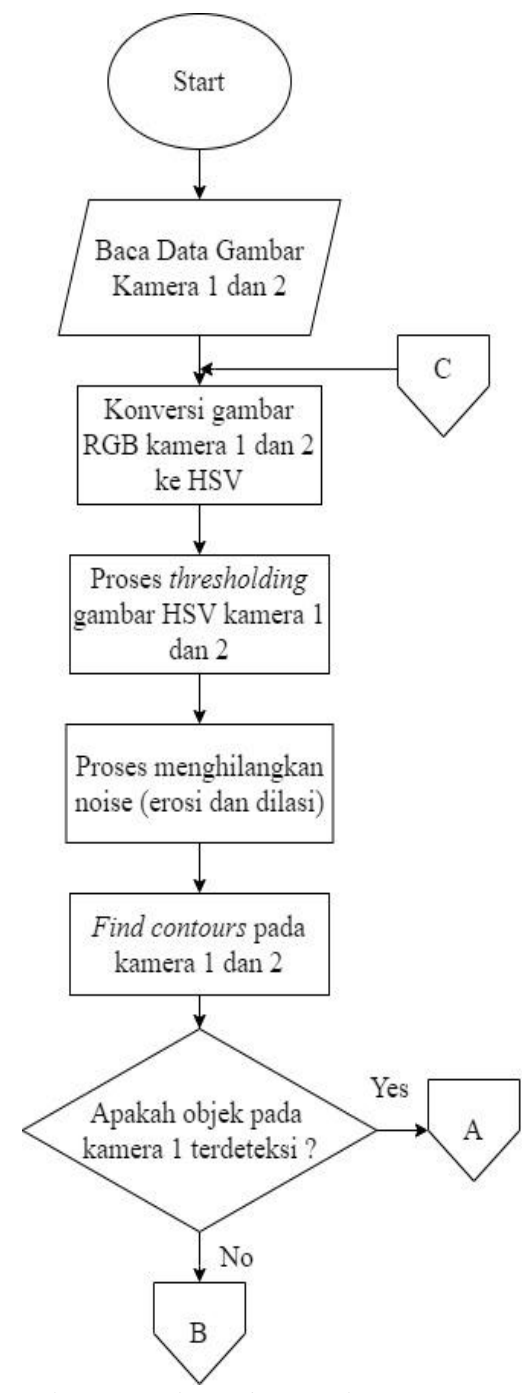

Gambar 5. Flowchart Algoritma

Color Filtering HSV

Gambar 5 menjelaskan bagaimana proses color filtering HSV yang selanjutnya hasil dari proses tersebut menjadi berbagai data yang dipengaruhi oleh posisi objek pada pixel kamera. Jika kamera 1 mendeteksi keberadaan objek yang berada di depan robot maka data koordinat objek yang dideteksi dikirim ke arduino mega yang selanjutnya akan menjadi kondisi dalam pergerakan aktuator, pada pendeteksian objek menggunakan kamera 1 memiliki 9 kondisi. Kondisi tersebut diperoleh dari posisi objek di dalam frame pixel kamera 1. Flowchart algoritma image processing pada kamera 1 dapat dilihat pada gambar 6.

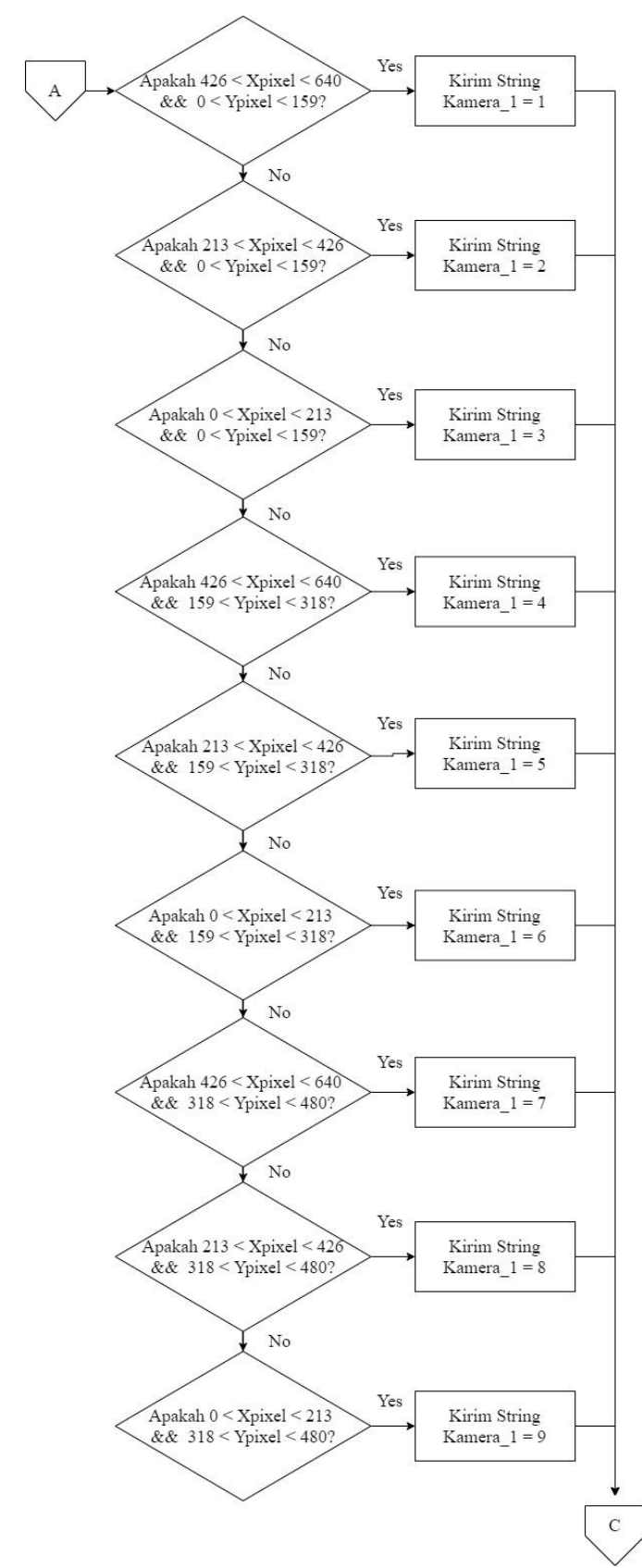

Gambar 6. Flowchart Algoritma Image Processing Kamera 1.

Apabila kamera 1 tidak mendeteksi objek yang berada di depan robot maka kamera 2 akan melakukan proses pendeteksian keberadaan objek $360^{\circ}$ disekitar robot. Selanjutnya laptop akan mengirimkan koordinat objek yang dideteksi oleh kamera 2 kepada kontroler yang menjadi kondisi dalam pergerakan aktuator.

Pada pendeteksian objek menggunakan kamera 2 memiliki 4 kondisi pergerakan aktuator. Kondisi tersebut diperoleh dari posisi objek di dalam frame pixel kamera 2. Flowchart algoritma image processing pada kamera 2 dapat dilihat pada gambar 7. 


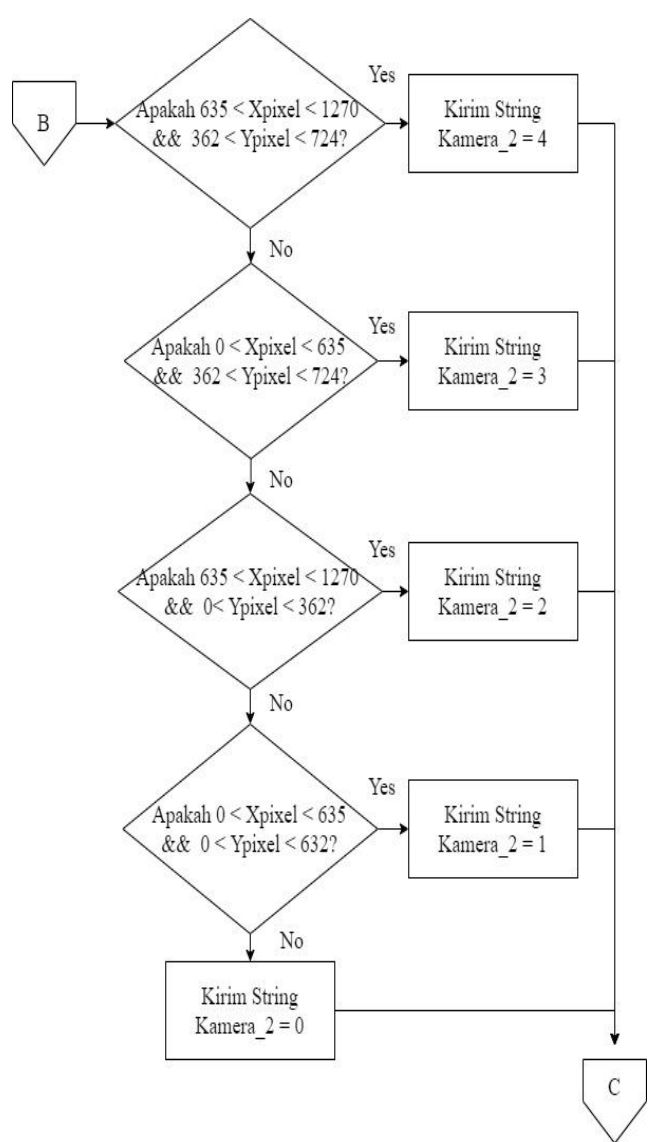

Gambar 7. Flowchart Algoritma Image Processing Kamera 2.

Pada gambar 7 apabila kamera 2 tidak mendeteksi keberadaan objek maka robot akan diam, hal ini dikarenakan oleh 2 hal yaitu tidak ada objek disekitar robot atau objek yang disekitar robot berada pada batas kemampuan sensor kamera dalam mendeteksi objek sehingga objek tidak terdeteksi.

Pengambilan gambar pada kedua kamera dilakukan secara realtime sehingga dapat dilihat pada gambar 6 dan 7 bahwa setelah proses pengolahan citra mendapatkan data posisi objek maka proses akan kembali ke pengambilan data gambar secara berulang dibagian $\mathrm{C}$ yang dapat dilihat pada gambar 5.

Data posisi objek pada kamera 1 dan 2 tersebut dikirimkan secara serial ke arduino mega menjadi kondisi dalam pergerakan robot. Adapun flowchart sistem pergerakan robot dapat dilihat pada gambar 8 .

Pada gambar 8 dapat dilihat penggunaan 2 kamera pada robot menghasilkan 14 kondisi pergerakan robot sehingga robot dapat melakukan pergerakan yang lebih efektif dibandingan dengan penggunaan 1 kamera yang terbatas pada area deteksi.

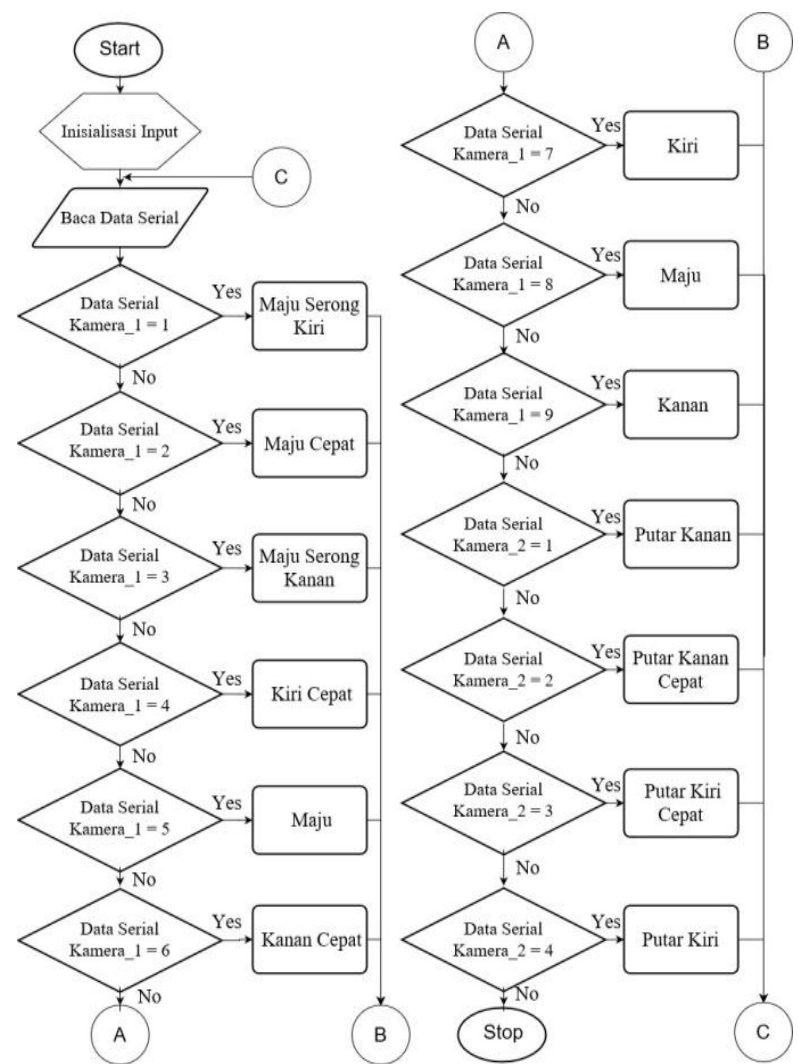

Gambar 8. Flowchart sistem pergerakan robot

\section{Perancangan Rangkaian}

Konfigurasi PIN dari driver motor BTS7960 yang digunakan pada arduino mega 2560 dalam penelitian ini dapat dilihat pada gambar 9.

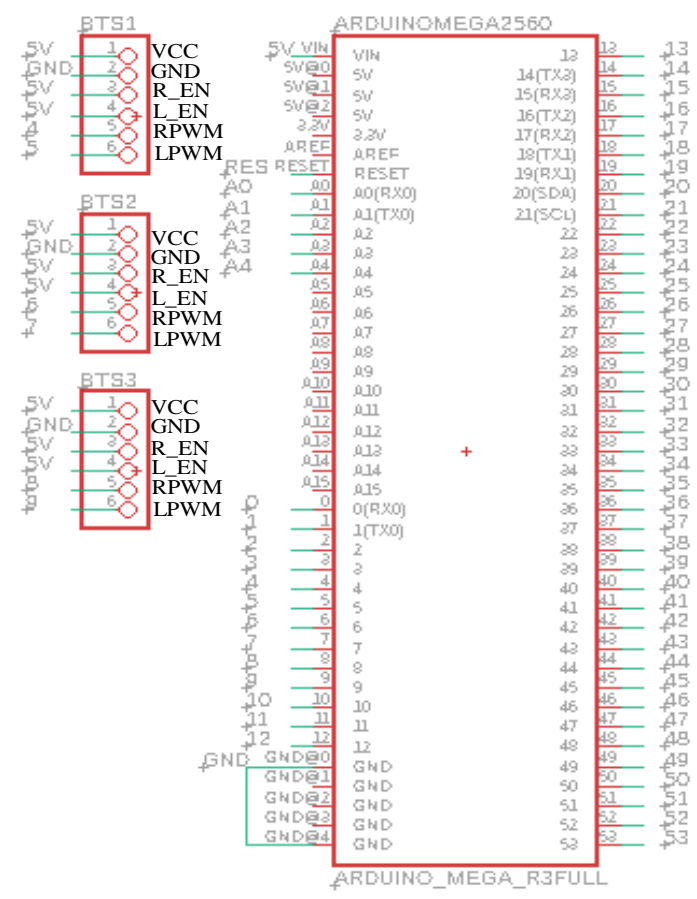

Gambar 9. Konfigurasi Pin Driver Motor BTS pada Arduino Mega 2560. 
D. Perancangan Software

Aplikasi yang digunakan pada perancangan software sistem pendeteksian objek pada penelitian ini adalah IDLE (Python GUI) yang dikomunikasikan atau dikomplikasi oleh pemrograman python dengan library OpenCV yang dibantu dengan bantuan image processing toolbox yang sudah tersedia. Aplikasi ini akan melakukan proses pengolahan citra yang diterima sampai perbaikan pengolahan citra. Pada perancangan software sistem pergerakan robot dengan Arduino mega 2560 sebagai kontroler diprogram dengan Arduino IDE.

E. Perancangan Mekanik

Robot sepak bola pada penelitian ini dirancang sesuai dengan aturan robot sepak bola beroda Indonesia dengan dimensi panjang dan lebar antara $30-52 \mathrm{~cm}$ dan tinggi robot antara 40 $80 \mathrm{~cm}$ [15]. Perancangan robot menggunakan aplikasi autodesk inventor dan proses manufacturing menggunakan bahan besi hollow dengan ukuran $20 \times 20 \mathrm{~mm}$, plat alumunium dengan tebal $3 \mathrm{~mm}$ dan bahan akrilik dengan tebal $3 \mathrm{~mm}$. Hal ini bertujuan agar robot dapat kuat dalam melakukan manuver dan benturan disaat bermain bola.

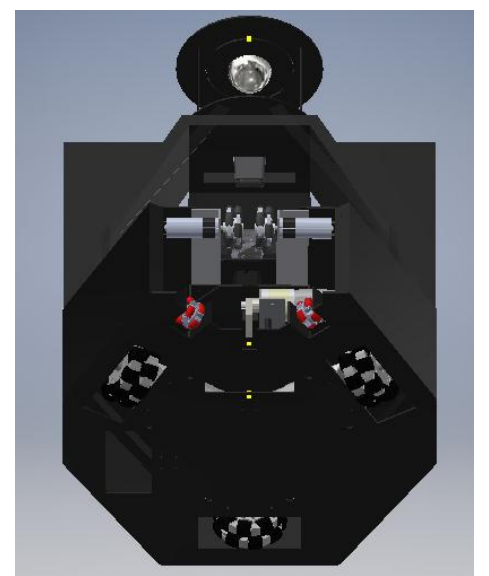

Gambar 10. Desain Tata Letak Omniwheels pada Robot Sepak Bola Beroda

Robot dilengkapi dengan lensa omni yang memantulkan keadaan sekeliling $360^{\circ}$. Hasil pantulan tersebut dimanfaatkan oleh kamera 2 untuk mengetahui keberadaan objek di sekitar robot, dibagian tengah robot digunakan sebagai tempat laptop yang bekerja melakukan proses image processing dan tempat kamera 1 untuk mengambil gambar objek yang berada di depan robot. Dibagian bawah robot terdapat Arduino mega 2560 yang sebagai kontroler, Driver motor yang mengontrol arah putaran dan kecepatan motor, regulator tegangan dan battery sebagai sumber energi listrik yang dibutuhkan oleh robot. Robot dirancang menggunakan 3 motor dengan roda omni diameter $100 \mathrm{~mm}$ sehingga robot dapat bergerak kesegala arah. Tata letak omniwheels pada penelitian ini dirancang dengan sudut posisi antar roda sejauh $120^{\circ}$ dan Desain Mekanik robot sepak bola beroda dirancang dengan ukuran $52 \mathrm{x}$ $52 \mathrm{~cm}$ dengan tinggi robot $75 \mathrm{~cm}$, tata letak omniwheels dan desain mekanik robot dapat dilihat pada gambar 10 dan 11.

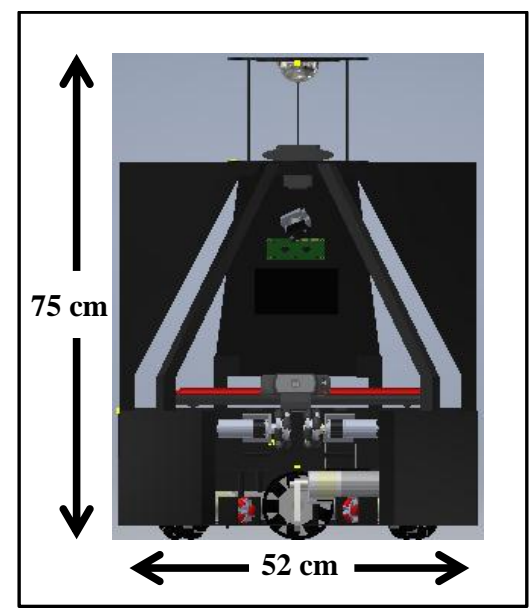

Gambar 11. Desain Mekanik Robot Sepak Bola Beroda

\section{HASIL DAN PEMBAHASAN}

Pada bagian hasil dan pembahasan dilakukan beberapa pengujian dan analisa pada seluruh bagian input dan output pada robot yang telah dirancang pada penelitian ini. Robot sepak bola beroda yang digunakan pada penelitian ini dapat dilihat pada gambar 12 .

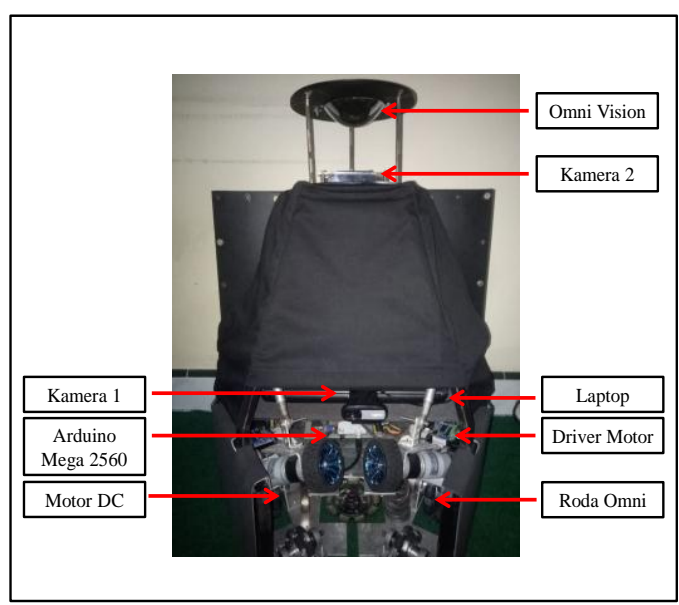

Gambar 12. Robot Sepak Bola Beroda

Pertama dilakukan pengujian penerapan algoritma color filtering $H S V$ untuk mengetahui apakah kamera melakukan pendeteksian objek 
dengan baik, selanjutnya akan dianalisa apakah output telah sesuai dengan yang diinginkan. Pertama dilakukan pengambilan citra asli secara realtime yang dapat dilihat pada gambar 13 .

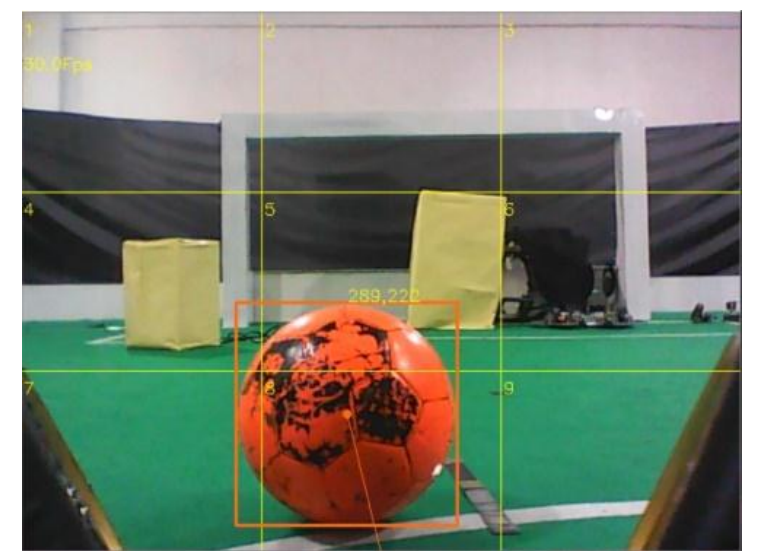

Gambar 13. Citra Asli Tangkapan Kamera

Selanjutnya citra asli pada gambar 13 dikonversi menjadi nilai model ruang warna HSV dengan persamaan 1- 4. Adapun nilai HSV yang digunakan pada penelitian ini dapat dilihat pada tabel 6.

Tabel 1. Nilai HSV Pada Kamera 1

\begin{tabular}{|c|c|c|c|c|c|c|c|}
\hline \multirow[b]{2}{*}{ NO } & \multirow[b]{2}{*}{$\begin{array}{l}\text { Warna } \\
\text { Output }\end{array}$} & \multicolumn{6}{|c|}{ Warna Input } \\
\hline & & $\begin{array}{c}\mathrm{H} \\
\mathrm{Max}\end{array}$ & $\begin{array}{c}\mathrm{H} \\
\mathrm{Min}\end{array}$ & $\begin{array}{c}\mathrm{S} \\
\mathrm{Max}\end{array}$ & $\begin{array}{c}\text { S } \\
\text { Min }\end{array}$ & $\begin{array}{c}\mathrm{V} \\
\mathrm{Max}\end{array}$ & $\begin{array}{c}\mathrm{V} \\
\mathrm{Min}\end{array}$ \\
\hline 1 & Oranye & 19 & 0 & 255 & 93 & 255 & 120 \\
\hline
\end{tabular}

Hasil dari perubahan citra asli menjadi citra HSV dapat dilihat pada gambar 14.

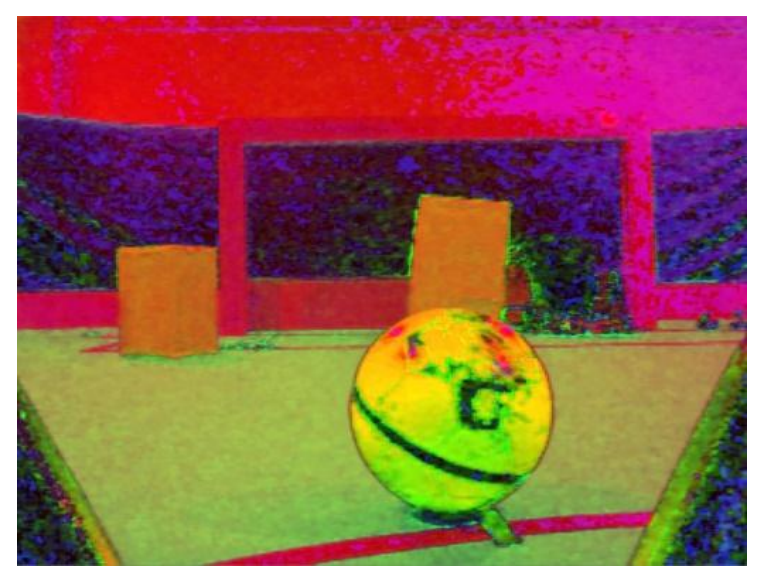

Gambar 14. Citra HSV

Hasil citra HSV pada gambar dibinarisasi, output dari proses binarisasi dapat dilihat pada gambar 15 .

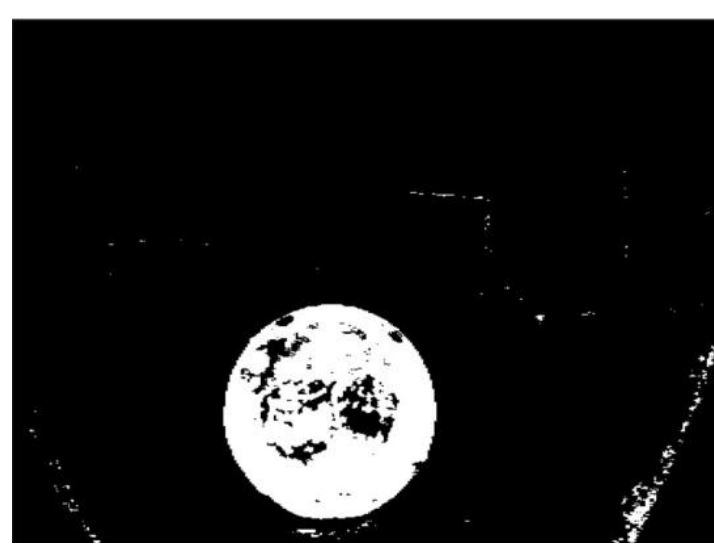

Gambar 15. Citra Binarisasi

Pada gambar terlihat bahwa masih banyak noise pada hasil citra binarisasi sehingga dilakukan filter morfologi untuk menghilangkan noise pada citra. Hasil dari citra yang telah diberikan filter morfologi dapat dilihat pada gambar 16.

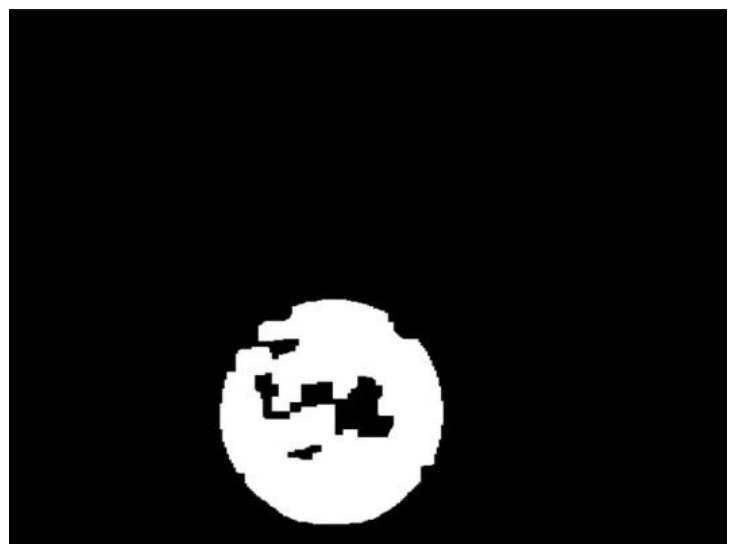

Gambar 16. Citra Hasil Filter Morfologi

Hasil dari filter morfologi merupakan output dari proses color filtering HSV. Selanjutnya dilakukan pengujian jarak objek yang dapat dideteksi oleh kamera 1. Jarak objek yang dapat dideteksi oleh kamera 1 dapat dilihat pada tabel 2 .

Tabel 2. Jarak Deteksi Objek Pada Kamera 1

\begin{tabular}{|c|c|c|c|}
\hline Jarak & Keterangan & Hasil \\
\hline 1 & $\begin{array}{c}\text { Objek } \\
\text { Terdeteksi }\end{array}$ & & \\
& & & 1 \\
\hline
\end{tabular}




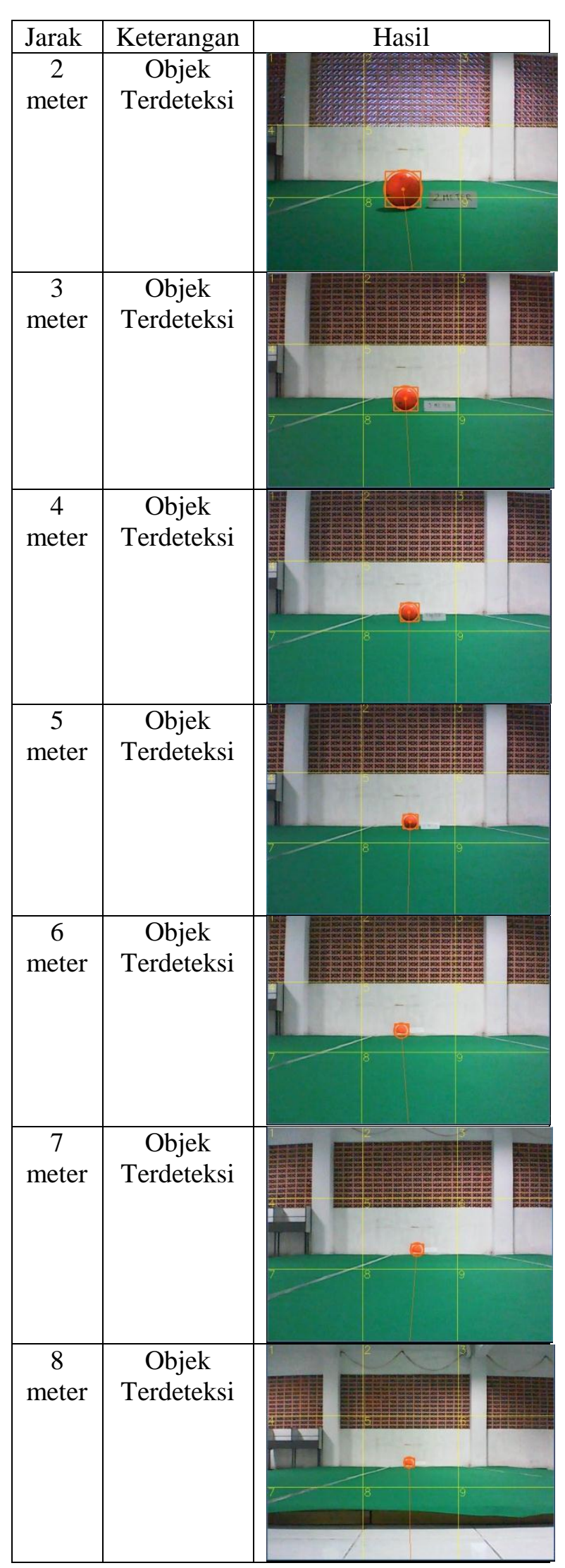

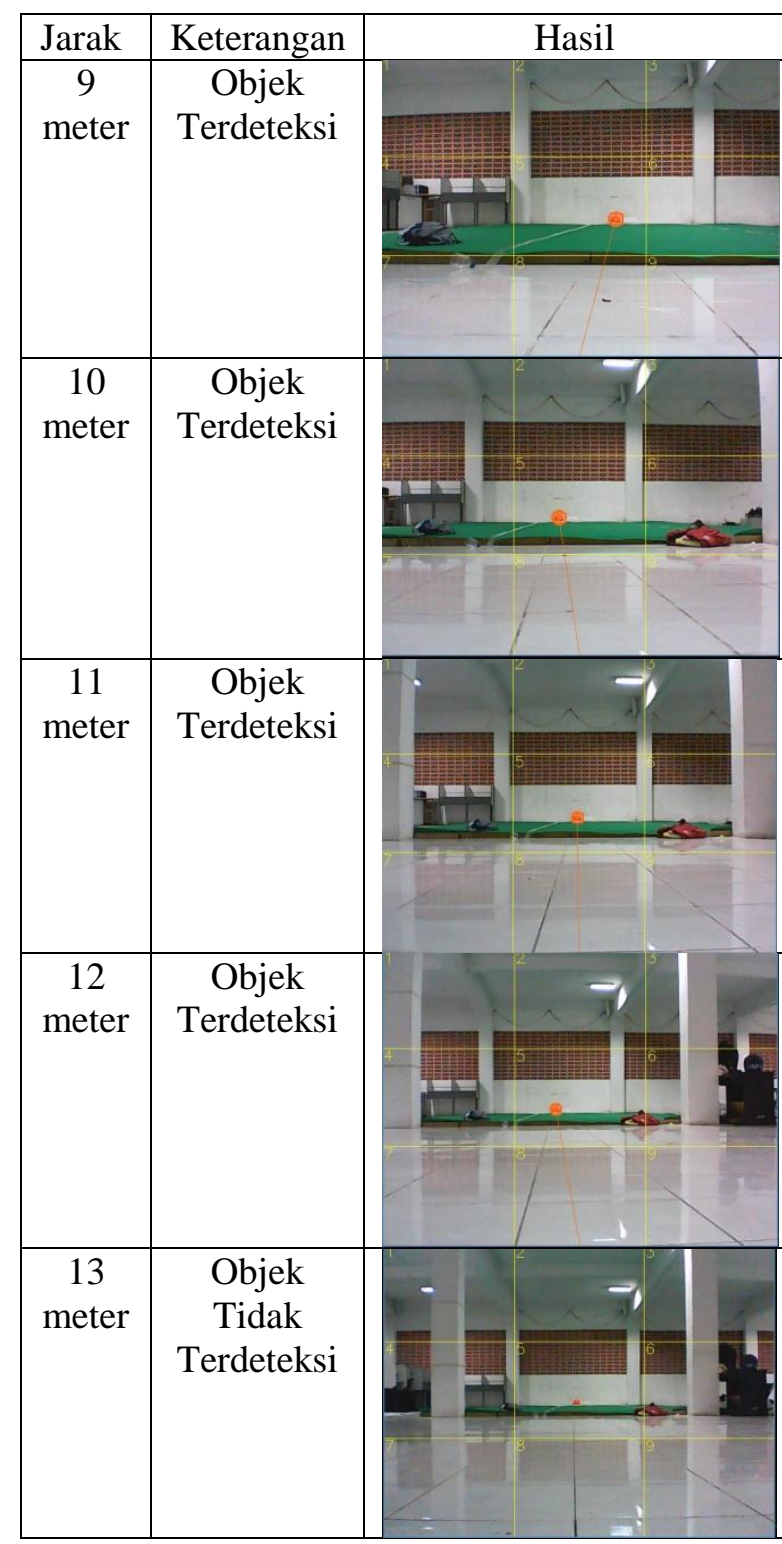

Proses color filtering HSV yang sama juga dilakukan pada kamera 2. Adapun nilai HSV yang digunakan pada penelitian ini dapat dilihat pada tabel 3.

Tabel 3. Nilai HSV Pada Kamera 2

\begin{tabular}{|c|c|c|c|c|c|c|c|}
\hline \multirow{3}{*}{ NO } & & \multicolumn{6}{|c|}{ Warna Input } \\
\cline { 3 - 8 } & Warna & O & H & S & S & V & V \\
& Output & Max & Min & Max & Min & Max & Min \\
\hline 1 & Oranye & 26 & 0 & 255 & 158 & 255 & 193 \\
\hline
\end{tabular}

Selanjutnya dilakukan pengujian jarak objek yang dapat dideteksi oleh kamera 2. Jarak objek yang dapat dideteksi oleh kamera 2 dapat dilihat pada tabel 4 . 
Tabel 4. Jarak Deteksi Objek Pada Kamera 2

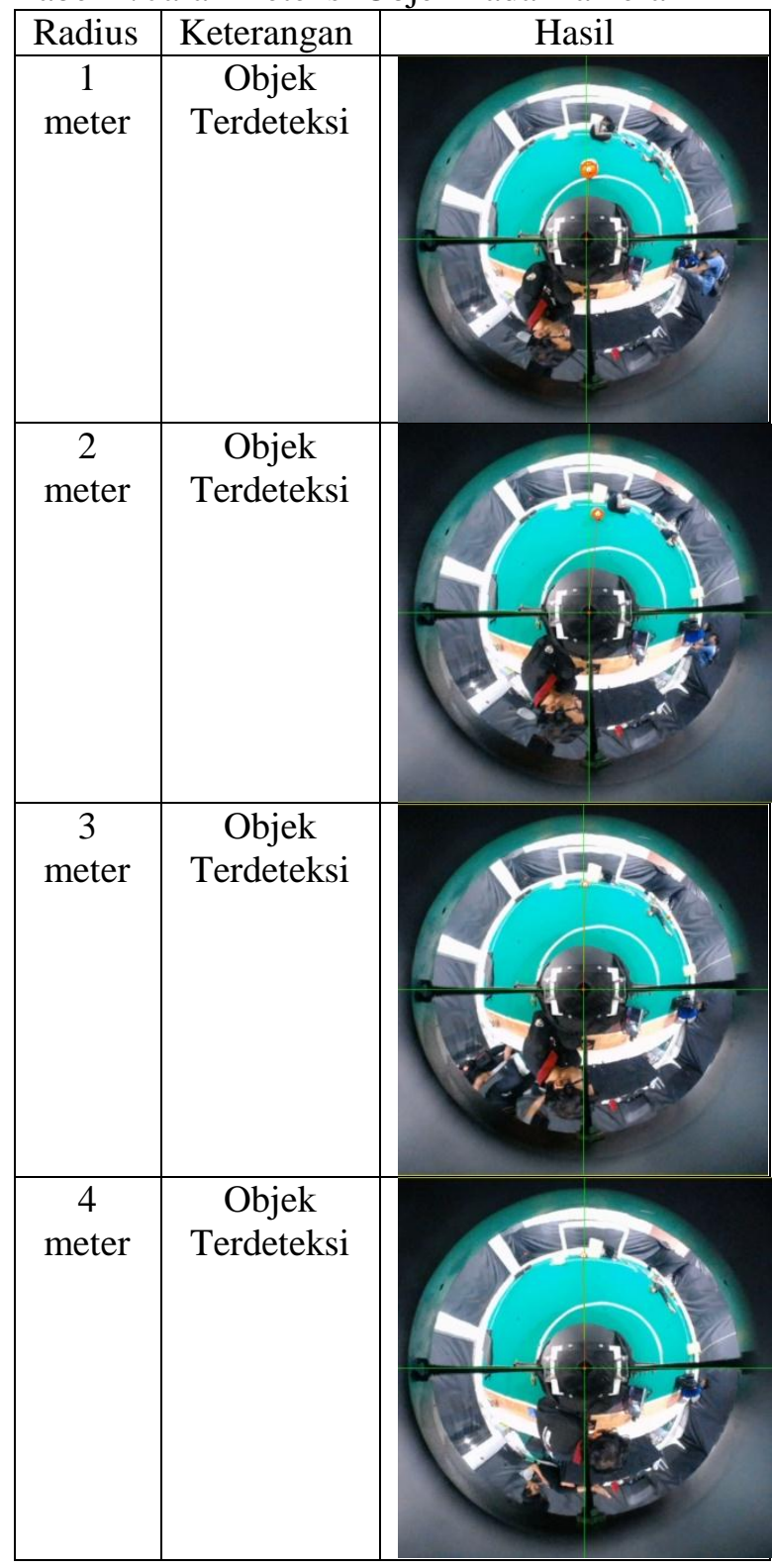

Selanjutnya dilakukan pengujian sistem pergerakan robot holonomic menggunakan konfigurasi 3 omniwheels. Pertama dilakukan pengujian variasi input logika high (1) dan low (0) pada motor DC yang digunakan. Hasil pengujian arah putaran motor dapat dilihat pada tabel 5 .

Tabel 5. Pengujian Arah Putaran Motor

\begin{tabular}{|c|c|c|c|}
\hline No & $\begin{array}{c}\text { Input } \\
1\end{array}$ & $\begin{array}{c}\text { Input } \\
2\end{array}$ & Kondisi Motor \\
\hline 1 & 0 & 0 & Motor Tidak Berputar \\
\hline 2 & 0 & 1 & $\begin{array}{c}\text { Motor Berputar Searah Jarum } \\
\text { Jam }\end{array}$ \\
\hline 3 & 1 & 0 & $\begin{array}{c}\text { Motor Berputar Berlawanan } \\
\text { Arah Jarum Jam }\end{array}$ \\
\hline 4 & 1 & 1 & Motor Tidak Berputar \\
\hline
\end{tabular}

Pengujian yang dilakukan pada tabel 2 menjadi referensi untuk pengujian pergerakan robot. Konfigurasi 3 roda omni pada robot beroda dapat menghasilkan pergerakan holonomic. Vektor sistem pergerakan robot dapat dilihat pada tabel 6 .

Tabel 6. Vektor Sistem Pergerakan Robot.

\begin{tabular}{|l|l|l|}
\hline No & Arah \\
\hline 1 & & Argerakan \\
\hline & & \\
\hline
\end{tabular}

Pada tabel 3 roda omni dipasang dengan perbedaan sudut antar roda adalah $120^{\circ}$. Perbedaan sudut tersebut menghasilkan nilai dan vektor pada sumbu x dan y. Dengan menerapkan persamaan (6) dan (7) sehingga robot dapat melakukan pergerakan ke kanan dan ke kiri tanpa mengubah arah hadap robot maka untuk pergerakan ke kiri roda 1 dan 2 harus begerak searah jarum jam dan roda 3 bergerak berlawanan arah jarum jam dengan kecepatan 2 kali lebih cepat dari kecepatan roda 1 dan 2. 
Sementara untuk pergerakan ke kanan roda 1 dan 2 harus begerak berlawanan arah jarum jam dan roda 3 bergerak searah jarum jam dengan kecepatan 2 kali lebih cepat dari kecepatan roda 1 dan 2. Selanjutnya untuk pergerakan maju atau mundur roda 3 harus dalam keadaan diam dan untuk pergerakan serong kanan roda 2 dalam keadaan mati sedangkan untuk serong kiri roda 1 dalam keadaan mati.

Pengujian pergerakan pada tabel 3 akan dikondisikan dengan posisi keberadaan objek pada kamera 1 dan 2. Keberadaan objek dalam sistem deteksi objek kamera 1 dapat dilihat pada gambar 17.

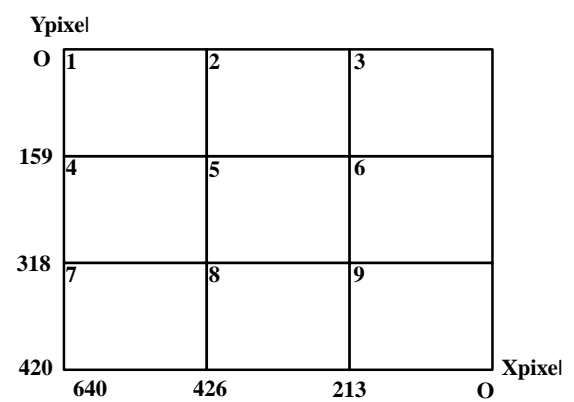

Gambar 17. Sistem Deteksi Objek Kamera 1

Pada gambar 17 sistem deteksi objek pada kamera 1 digunakan resolusi $(640,420)$ dan dibagi kedalam 9 bagian. Posisi objek Xpixel dan Ypixel pada bagian-bagian tersebut menjadi data variabel kamera_1 yang akan dikirim ke arduino mega 2560. Jika kamera 1 tidak mendeteksi keberadaan objek di depan robot maka sistem deteksi objek kamera 2 akan bekerja untuk mendeteksi keberadaan objek disekitar robot. Sistem deteksi objek kamera 2 dapat dilihat pada gambar 18.

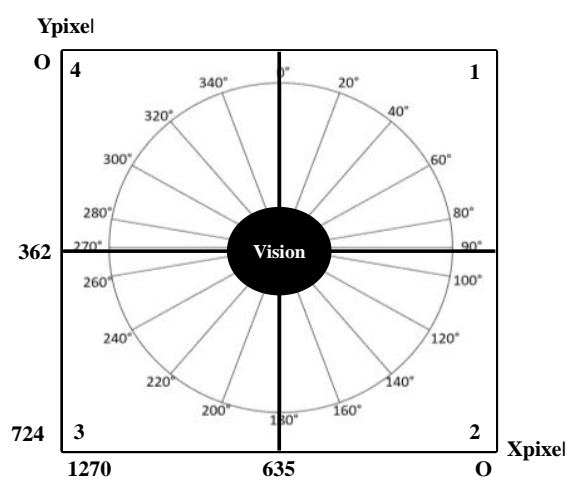

Gambar 18. Sistem Deteksi Objek Kamera 2

Pada gambar 18 sistem deteksi objek pada kamera 2 menggunakan resolusi $(1270,724)$, dan dibagi kedalam 4 posisi, pada sistem ini kamera memanfaatkan pantulan lensa omni untuk dapat melihat $360^{\circ}$, koordinat objek pada Xpixel dan Ypixel menjadi data variabel kamera_2 yang akan dikirim ke arduino mega 2560. Apabila tidak ada objek yang dideteksi oleh kamera 1 dan 2 maka robot tidak akan bergerak. Pengujian pergerakan robot terhadap posisi objek yang dideteksi dapat dilihat pada tabel 7 .

Tabel 7. Pergerakan Robot Terhadap Posisi Objek

\begin{tabular}{|c|c|c|c|}
\hline \multirow[b]{2}{*}{ No } & \multicolumn{2}{|c|}{ Data Koordinat } & \multirow{2}{*}{$\begin{array}{c}\text { Kondisi / } \\
\text { Pergerakan Robot }\end{array}$} \\
\hline & Xpixel & Ypixel & \\
\hline 1 & $426-640$ & $0-159$ & $\begin{array}{c}\text { Kamera_1 = 1/ } \\
\text { Serong Kiri }\end{array}$ \\
\hline 2 & $213-426$ & $0-159$ & $\begin{array}{l}\text { Kamera_1 = 2/ } \\
\text { Maju Cepat }\end{array}$ \\
\hline 3 & $0-213$ & $0-159$ & $\begin{array}{l}\text { Kamera_1 } 1=3 / \\
\text { Serong Kanan }\end{array}$ \\
\hline 4 & $426-640$ & $159-318$ & $\begin{array}{c}\text { Kamera_1 } 1=4 / \\
\text { Kiri Cepat }\end{array}$ \\
\hline 5 & $213-426$ & $159-318$ & $\underset{\text { Maju }}{\text { Kamera_1 }}=5 /$ \\
\hline 6 & $0-213$ & $159-318$ & $\begin{array}{l}\text { Kamera_1 = 6/ } \\
\text { Kanan Cepat }\end{array}$ \\
\hline 7 & $426-640$ & $318-480$ & $\begin{array}{c}\text { Kamera_1 } 1=7 / \\
\text { Kiri }\end{array}$ \\
\hline 8 & $213-426$ & $318-480$ & $\begin{array}{c}\text { Kamera_1 } \\
\text { Maju }\end{array}=8 /$ \\
\hline 9 & $0-213$ & $318-480$ & $\begin{array}{c}\text { Kamera_1 }=9 / \\
\text { Kanan }\end{array}$ \\
\hline 10 & $0-635$ & $0-362$ & $\begin{array}{c}\text { Kamera_2 = 1/ } \\
\text { Putar Kanan }\end{array}$ \\
\hline 11 & $635-1270$ & $0-362$ & $\begin{array}{c}\text { Kamera_2 }=2 / \\
\text { Putar Kanan Cepat }\end{array}$ \\
\hline 12 & $0-635$ & $362-724$ & $\begin{array}{l}\text { Kamera_1 = 3/ } \\
\text { Putar Kiri Cepat }\end{array}$ \\
\hline 13 & $635-1270$ & $362-724$ & $\begin{array}{c}\text { Kamera_1 = 4/ } \\
\text { Putar Kiri } \\
\text { Kamera } 1 \& \&\end{array}$ \\
\hline 14 & 0 & 0 & $\begin{array}{c}\text { Kamera } \_2=0 / \\
\text { Diam }\end{array}$ \\
\hline
\end{tabular}

\section{KESIMPULAN}

Berdasarkan hasil penelitian dan pengujian yang telah dilakukan diperoleh kesimpulan bahwa metode color filtering HSV yang diterapkan dapat melakukan pendeteksian objek dengan baik sehingga noise pada hasil pengolahan citra dapat dihilangkan.

Penerapan metode tesebut pada multivision untuk sistem pendeteksian objek robot sepak bola beroda dapat memperluas area deteksi robot hingga $360^{\circ}$. Hasil pengujian juga menunjukkan bahwa jarak deteksi objek untuk kamera 1 adalah 12 meter sedangkan radius deteksi objek untuk kamera 2 adalah 4 meter. Penerapan multivision pada robot sepak bola dapat memberikan efektifitas pada sistem pergerakan robot. Hal ini disebabkan oleh lebih banyaknya kondisi pergerakan yang dapat dilakukan oleh robot. Serta 
penggunaan 3 omniwheels sebagai sistem pergerakan pada robot sepak bola menciptakan sistem pergerakan robot yang holonomic.

\section{DAFTAR PUSTAKa}

[1] Raharjo Agung, Ibadillah Ahmad Fiqhi, Joni Koko," Sistem Deteksi Objek dan Posisi pada Robot Sepak Bola Beroda Middle Size pada Sistem Kamera Omni Vision dengan Scan Lines" the 6th Indonesian Symposium on Robotic System and Control. 2018.

[2] Simon, Andrea. "Implementasi Color Model Filtering HSV Untuk Mendeteksi Bola Pada Robot Sepak Bola Beroda". Medan: Universitas Sumatera Utara, 2018.

[3] S. Kolkur, (2017),"Human Skin Detection Using RGB, $\mathrm{HSV}$, and $\mathrm{YCBCr}$ color Model",Atlantis press.

[4] Handriko, Irwan, Nugrah Iqbal, "Penerapan Metode Color Filtering HSV Untuk Pendeteksian Bola Pada Robot KRSBI Beroda" the 6th Indonesian Symposium on Robotic System and Control. 2018.

[5] Zainal Abidin,"Rancang Bangun Robot Penghindar Halangan Berbasis Kamera Menggunakan Deteksi Kontur," Program Studi S1 Teknik Elektro, Universitas Trunojoyo Madura, Indonesia, 2017.

[6] Tantra Pandu Surya, Ismail Muhammad Azhar, Ma'ruf Dhiaul, dkk "Penggunaan Kamera Global Untuk Menentukan Koordinat Robot Pada Lapangan" the 6th Indonesian Symposium on Robotic System and Control. 2018.

[7] R. Wahyusari dan B. Haryoko. (2017) "Pemanfaatan Mathematical Morphology untuk Deteksi Tepi Batik", Jurnal Simetris, vol 8 no 1.

[8] T. Fitrah dan S. Budi.(2018)“Robot Pengikut Posisi dengan Menggunakan Filter Warna HSV", Jurnal Integrasi, vol 10 no 2.

[9] Anggri Yulio P. 2017. Operasi Morfologi Pada Pengolahan Citra di https://devtrik.com/opencv/operasi-morfologipada-pengolahan-citra/ (diakses 4 Juni 2020).

[10] Prianggodo, Laksono Budi. "Perancangan Object Tracking Robot Berbasis Image Processing Menggunakan Raspberry Pi”.
Surakarta: Universitas Muhammadiyah Surakarta, 2016.

[11] Risfendra, Asfinaldi, Habibullah, Sardi Juli. "Sistem Pergerakan Robot Kiper Beroda Menggunakan Metode Wall Follower Berbasis Image Processing". ELKHA Jurnal Teknik Elektro Vol 12, No. 1, 2020

[12] Moreno J, Clotet E, Lupiañez R, Tresanchez M, Martínez D, Pallejá T, et al. Design, implementation and validation of the threewheel holonomic motion system of the assistant personal robot (APR). Sensors (Switzerland). 2016;16(10).

[13] Yani Ahmad, Joni Koko, Alfita Riza, "Sinkronisasi Pergerakan Robot Sepak bola Beroda Menggunakan Metode PID dan Odometry" the 6th Indonesian Symposium on Robotic System and Control. 2018.

[14] Wibowo Irwan Kurnianto, Bactiar Mochamad Mobet, Bayu Bima, dkk "Penentuan Posisi Robot Menggunakan Odometry Omniwheels" the 6th Indonesian Symposium on Robotic System and Control. 2018.

[15] Ristekdikti. (2018). Panduan KRSBI beroda 2018. Jakarta Pusat: Ristekdikti.

\section{Biodata Penulis}

Risfendra, S.Pd, MT, Ph.D, lahir di Riau, 13 Februari 1979. Sarjana Teknik Elektronika di Universitas Negeri Padang, lulus tahun 2004, S2 Teknik Sistem Pengaturan, ITS tahun 2008. S3 Shouten Taiwan University, of science and technology, Taiwan tahun 2017. Staf pengajar pada Jurusan Teknik Elektro FT UNP sejak tahun 2005 - sekarang.

Aldo Aulia Akbar, lahir di Padang, 27 Januari 1999. Mahasiswa di jurusan Teknik Elektro FT UNP sejak tahun 2016 - sekarang.

Firdaus, S.T, M.T, lahir di Bengkulu, 1977. Sarjana Teknik Elektronika di ITS, lulus tahun 2002, S2 Teknik Elektronika, ITS lulus tahun 2011. Staf pengajar pada Departemen Teknik Elektro Politeknik Negeri Padang. 